\title{
Beryl Ore
}

National Cancer Institute

\section{Source}

National Cancer Institute. Beryl Ore. NCI Thesaurus. Code C45882.

A transparent, beryllium-containing, naturally occurring mineral that forms distinctive hexagonal crystals in a variety of colors due to different impurities that emits toxic fumes of beryllium oxides upon heating and is colorless in its pure form. Beryl ore is found in deeply buried rocks mainly in pegmatites. This mineral is primarily used to produce beryllium metal and beryllium compounds for use in high-technology applications in the nuclear, electronics, defense, aerospace and ceramics industry. Inhalation exposure to its dust and fumes irritates the nose, throat and lungs and can cause pneumonitis.

Prolonged exposure can result in a chronic beryllium disease called berylliosis causing granuloma and fibrosis formation in the lungs. Beryllium is associated with an increased risk of developing lung cancer. ( $\mathrm{NCI05)}$ 